\title{
Gender difference on the knowledge, attitude, and practice of COPD diagnosis and treatment: a national, multicenter, cross-sectional survey in China
}

This article was published in the following Dove Press journal:

International Journal of COPD

\author{
Guohua Jia \\ Ming Lu \\ Rui Wu \\ Yahong Chen \\ Wanzhen Yao \\ Department of Pulmonary and \\ Critical Care Medicine, Peking \\ University Third Hospital, Beijing, \\ China
}

Correspondence: Rui Wu; Yahong Chen Department of Pulmonary and Critical Care Medicine, Peking University Third Hospital, No 49 North Garden Road I0019I, Beijing, China

Tel +86 I 366 I I0 5506;

+86 । $56 \mid 1908216$

Fax +861082266699 .

+861082266699

Email wuerui7518@sina.com;

chenyahong@vip.sina.com
Purpose: To investigate the gender difference in knowledge, attitude, and practice of COPD diagnosis and treatment in China.

Patients and methods: A nationwide, multicenter, cross-sectional questionnaire study was carried out to investigate patients' understanding and experience of COPD between September 2007 and December 2008.

Results: Two thousand and seventy-two patients were recruited from eleven centers. The final effective questionnaires were those of 1,698 cases, of which $32 \%$ were female. Women were younger, had higher body mass index, were more never smokers, and had lesser pack-years (all $P<0.01$ ). More women had under elementary education level and monthly income $<1,000$ RMB (about 160 USD) (all $P<0.01$ ). Women had higher ratio of $\mathrm{FEV}_{\mathrm{l}} / \mathrm{FVC}(54.1 \pm 10.9$ vs $50.2 \pm 11.5), \mathrm{FEV}_{1} \%$ (50.0 \pm 19.1 vs $\left.45.4 \pm 29.0\right)$, and lower short form-36 mental component summary (57.5 \pm 26.8 vs $61.3 \pm 25.0)$ (all $P<0.01$ ). Fewer women reported severe exacerbation (defined as an acute worsening of respiratory symptoms that results in patient's hospitalization) in the previous year $(44.5 \%$ vs $51.6 \%, P<0.05)$. More women reported that they never heard of COPD before $(67.0 \%$ vs $59.0 \%, P<0.01)$. Less women reported that physician had to tell them they had emphysema ( $50.5 \%$ vs $60.4 \%$ ) or COPD (31.9\% vs $37.9 \%)$. Less women had pulmonary function test (PFT) done before $(65.2 \%$ vs $70.4 \%, P<0.05)$. More women reported that they would not repeat PFT annually $(91.7 \%$ vs $87.6 \%, P<0.05)$ and did not know the PFT results $(78.6 \%$ vs $73.1 \%, P<0.05)$. More women reported not having had pulmonary rehabilitation before $(87.8 \%$ vs $83.6 \%, P<0.05)$. Fewer women reported knowing that COPD should be given combined therapy ( $38.3 \%$ vs $44.5 \%$ ) and long-term treatment ( $46.1 \%$ vs $51.9 \%$ ) (all $P<0.05$ ).

Conclusion: Male and female patients had different experiences on COPD diagnosis and treatment. Physicians should pay more attention to patients' education on COPD, especially of women.

Keywords: chronic obstructive pulmonary disease, sex, perception, experience, education, management

\section{Introduction}

COPD is a disease characterized by airflow limitation that is not fully reversible. As a major public health problem, COPD is the third leading cause of death in China. ${ }^{1}$ The overall prevalence of COPD was $8.2 \%$ in 2004 (men 12.4\%; women 5.1\%) and $8.6 \%$ in 2015 (men 11.9\%; women 5.4\%), accounting for 99.9 million people in China. ${ }^{2,3}$ It is notable that in our national epidemiology survey, prevalence of COPD is increasing, but only $12.0 \%$ of people with COPD had a pulmonary function test 
(PFT) done before, in which only 9.4\% were women, which is statistically less than men $(13.2 \%){ }^{2}$ Patients have little understanding on COPD compared with the knowledge of hypertension and diabetes mellitus, while the health care professionals have little information on patients' experience. The correct information exchange between patients and health care professionals can help in early detection of COPD. Patient education has been shown to be an effective method to improve patients' understanding of the disease and treatment. There have been few studies examining patients' understanding of COPD.

Traditionally, we regarded COPD as a male disease, which primarily affected men. However, epidemiology survey showed us a different standpoint. COPD deaths in women firstly surpassed men in 2004 in the USA, and the prevalence of COPD in women was higher than men in the USA, Canada, the Netherlands, and Australia. ${ }^{4-7}$ Also, in our national epidemiology study, COPD in women increased from $5.1 \%$ in 2004 to $5.4 \%$ in 2015 , which represents 31.2 million people in China.,3 Women are at greater risk of smoking-induced lung function impairment, more severe dyspnea, and poorer health status for the same level of tobacco exposure, and the number of women smokers is increasing. ${ }^{8-10}$ In addition, women have more chances of exposure to biomass smoke, which causes nonsmokers with COPD also more likely to be female. ${ }^{11-14}$ The risk factors may justify the current "prevalence" (only 10\% have spirometry) of COPD; nonetheless, the alleged increase (from 5\% to 5.4\%) from 2005 to 2014 seems insignificant. Despite this, research suggests that physicians are still "gender biased" in diagnosing COPD, as a general practitioner is more likely to diagnose men with COPD. ${ }^{15}$ The delayed diagnosis or misdiagnosis of COPD in women may cause poor prognosis. ${ }^{16,17}$ The degree to which these observations represent biologic, physiologic, or sociologic differences is not addressed. In addition, new evidence is emerging that men and women may be phenotypically different in their response to tobacco smoke, with men being more prone to an emphysematous phenotype and women to an airway predominant phenotype. ${ }^{18}$ Although information regarding differences in disease biology and clinical presentation between men and women is emerging, knowledge regarding gender difference in disease perception and experience is lacking.

Our research aim, therefore, was to explore the gender difference in understanding the disease from the perspectives of patients with COPD in a nationwide, multicenter study. The results will provide better education and management for patients, prevent disease progression, improve the quality of life and adherence, and reduce social burden between genders.

\section{Patients and methods Study design and patients}

This study was a retrospective database analysis. Nationwide cross-sectional surveys of patients with COPD were conducted in China including eleven tertiary hospitals from September 2007 to December 2008. These eleven hospitals were chosen because they represented different parts of China. The study was approved by the ethical committee of Peking University Third Hospital, Beijing, China. All data in the database were de-identified.

\section{Patients' survey}

Outpatients with COPD were recruited consecutively. COPD was diagnosed according to the criteria recommended by the Chinese Medical Society. ${ }^{19}$ Chronic airflow limitation was defined as a post-bronchodilator ratio of $\mathrm{FEV}_{1} / \mathrm{FVC}$ being $<70 \%$. Bronchodilator reversibility test revealed an increase in $\mathrm{FEV}_{1}<12 \%$ or $200 \mathrm{~mL}$ above the pre-bronchodilator $\mathrm{FEV}_{1}$ after inhalation of $400 \mu \mathrm{g}$ of salbutamol. Static lung volumes were measured in all patients using body plethysmography when appropriate. Patients were asked if they had comorbidities such as hypertension, coronary artery disease, diabetes, cerebrovascular disease, or other diseases. Patients with asthma, bronchiectasis, lung cancer, active lung tuberculosis, psychiatric diseases, cognitive dysfunction, or left heart failure were excluded from the study. Information on the use of drugs was also acquired by asking patients. The Chinese validated version of short form-36 (SF-36) was administered by trained researchers in each center. ${ }^{20}$ Each patient was interviewed once.

\section{Questionnaire items}

The questionnaire was designed according to the literature with modification. A panel of COPD experts helped draft the questionnaires. The demographics, and patients' knowledge, attitude, and practice of COPD were included in the questionnaire. Patients' knowledge, attitude, and practice on COPD diagnosis and treatment were measured by a series of questions; the answer was dichotomic or ranked by patients. For most questions, the answers to be selected were yes, no, or do not know, and some questions had some items to be ranked (Supplementary material). Dyspnea severity was measured by the mMRC Dyspnea Index. Stages of COPD were defined according to the original GOLD criteria based on $\mathrm{FEV}_{1} \%$ predicted. ${ }^{21}$ The investigators in each center were 
trained before the study. Patients were interviewed face to face by the investigators.

\section{Statistical analyses}

All statistical analyses were conducted with SPSS 21.0 (IBM Corporation, Armonk, NY, USA). Descriptive data were expressed as mean \pm SD or proportion (\%). Differences between the two groups were tested using the Student's $t$-test or the chi-squared test, when appropriate. The independent effects of gender on the knowledge, attitude, and practice of COPD were evaluated with logistic regression models. All $P$-values were two-tailed, with $P<0.05$ considered statistically significant.

\section{Results \\ Patients' demographics}

Two thousand and seventy-two patients were interviewed in the eleven centers. The final effective questionnaires were 1,698 after exclusion of 337 cases without PFT results and 38 cases who did not meet the COPD PFT criterion (Figure 1). The characteristics of the patients are shown in Table 1;32\% of the patients were female. Relative to male patients, women were younger ( $64.9 \pm 11.2$ vs $67.6 \pm 10.9$ years old), had higher body mass index $\left(23.2 \pm 4.2\right.$ vs $\left.22.2 \pm 3.7 \mathrm{~kg} / \mathrm{m}^{2}\right)$, were more never smokers (63.6\% vs $13.4 \%)$, and had lesser pack-years (26.0 \pm 23.2 vs $36.5 \pm 25.9$ ) (all $P<0.01$ ). More women were farmers $(31.7 \%$ vs $17.5 \%)$, with under elementary education level $(28.6 \%$ vs $9.5 \%)$ and a monthly income of $<1,000$ RMB (about 160\$; 61.4\% vs 30.4\%), and without medical

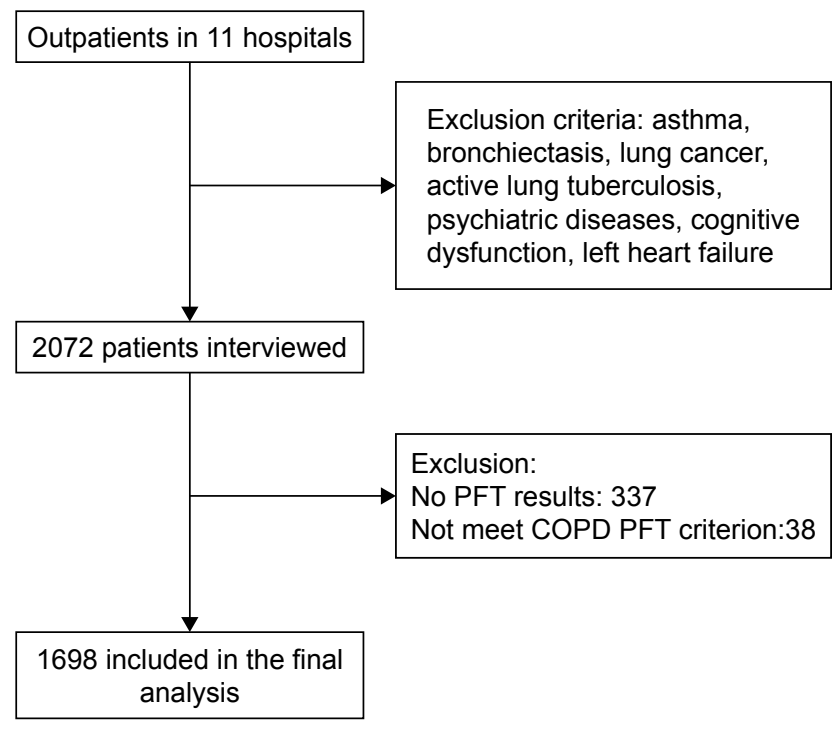

Figure I Flow of participants through the study. Abbreviation: PFT, pulmonary function test.
Table I Patient demographics

\begin{tabular}{|c|c|c|c|}
\hline & $\begin{array}{l}\text { Male } \\
(n=1,156)\end{array}$ & $\begin{array}{l}\text { Female } \\
(n=542)\end{array}$ & $P$-value \\
\hline Age, years (mean $\pm S D)$ & $67.6 \pm 10.9$ & $64.9 \pm 11.2$ & $<0.01$ \\
\hline BMI $\left(\mathrm{kg} / \mathrm{m}^{2}\right)($ mean $\pm \mathrm{SD})$ & $22.2 \pm 3.7$ & $23.2 \pm 4.2$ & $<0.01$ \\
\hline \multicolumn{4}{|l|}{ Smoking history, n (\%) } \\
\hline Current smoker & $298(26.0 \%)$ & $79(14.6 \%)$ & $<0.01$ \\
\hline Never smoker & $153(13.4 \%)$ & $344(63.6 \%)$ & $<0.01$ \\
\hline Ex-smoker & $693(60.6 \%)$ & $118(21.8 \%)$ & $<0.01$ \\
\hline Pack-years (mean $\pm S D)$ & $36.5 \pm 25.9$ & $26.0 \pm 23.2$ & $<0.01$ \\
\hline $\begin{array}{l}\text { Education under elementary, } \\
\mathrm{n}(\%)\end{array}$ & $109(9.5 \%)$ & I55 (28.6\%) & $<0.01$ \\
\hline \multicolumn{4}{|l|}{ Occupation, n (\%) } \\
\hline Farmer & $202(17.5 \%)$ & $172(31.7 \%)$ & $<0.01$ \\
\hline No work & $232(20.1 \%)$ & $250(46.1 \%)$ & $<0.01$ \\
\hline No insurance, n (\%) & $299(26.0 \%)$ & $246(45.5 \%)$ & $<0.01$ \\
\hline $\begin{array}{l}\text { Monthly income } \leq \mathrm{I}, 000 \\
\text { (RMB), } \mathrm{n}(\%)\end{array}$ & $348(30.4 \%)$ & $333(61.4 \%)$ & $<0.01$ \\
\hline
\end{tabular}

Abbreviation: BMI, body mass index.

insurance (45.5\% vs $26.0 \%$ ) or work (46.1\% vs $20.1 \%$ ) (all $P<0.01$; Table 1).

\section{Disease severity, comorbidities, exacerbation, and quality of life}

Relative to male patients, women had higher $\mathrm{FEV}_{1} / \mathrm{FVC}$

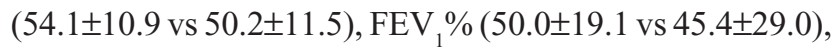

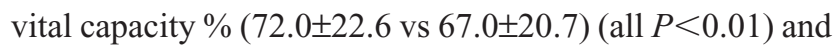
lower residual volume/total lung capacity $(58.5 \pm 23.2$ vs $62.7 \pm 33.9, P<0.05)$. However, women rated $\mathrm{mMRC}$ dyspnea score similar to men $(1.74 \pm 1.10$ vs $1.70 \pm 1.11, P>0.05)$. They had similar comorbidities: hypertension (56.0\% vs $56.3 \%)$, coronary artery disease (30.3\% vs $30.6 \%)$, diabetes $(18.3 \%$ vs $16.8 \%$ ), and cerebrovascular disease (7.9\% vs $10.6 \%$ ) (all $P>0.05)$. Less women reported severe exacerbation (defined as an acute worsening of respiratory symptoms that results in patients' hospitalization) in the previous year (44.5\% vs $51.6 \%, P<0.05)$. The number of exacerbations in the past year $(2.55 \pm 2.93$ vs $2.47 \pm 2.68)$ and the percentage of one or more exacerbations ( $84.3 \%$ vs $87.0 \%$ ) were similar between women and men. Regarding the quality of life, women had lower SF-36 mental component summary (57.5 \pm 26.8 vs $61.3 \pm 25.0, P<0.01)$ and similar SF-36 physical component summary to men, as shown in Table 2.

\section{Patients' knowledge about COPD diagnosis}

Patients' knowledge about COPD diagnosis was assessed by the items that were heard of COPD and the risk factors 
Table 2 Gender difference on disease severity, comorbidities, exacerbation, and quality of life

\begin{tabular}{|c|c|c|c|}
\hline & $\begin{array}{l}\text { Male } \\
(n=I, 156)\end{array}$ & $\begin{array}{l}\text { Female } \\
(\mathrm{n}=542)\end{array}$ & $P$-value \\
\hline \multicolumn{4}{|l|}{ COPD stage, n (\%) } \\
\hline Stage I & $72(6.3)$ & $45(8.4)$ & $>0.05$ \\
\hline Stage II & $308(27.1)$ & $22 I(4 I . I)$ & $<0.01$ \\
\hline Stage III & $439(38.7)$ & $188(34.9)$ & $>0.05$ \\
\hline Stage IV & $316(27.8)$ & $84(15.6)$ & $<0.01$ \\
\hline $\mathrm{FEV}_{1} / \mathrm{FVC}($ mean $\pm \mathrm{SD})$ & $50.2 \pm 11.5$ & $54.1 \pm 10.9$ & $<0.01$ \\
\hline $\mathrm{FEV}, \%($ mean $\pm \mathrm{SD})$ & $45.4 \pm 29.0$ & $50.0 \pm 19.1$ & $<0.01$ \\
\hline VC\% (mean \pm SD) & $67.0 \pm 20.7$ & $72.0 \pm 22.6$ & $<0.01$ \\
\hline $\mathrm{RV} / \mathrm{TLC} \%(\operatorname{mean} \pm \mathrm{SD})$ & $62.7 \pm 33.9$ & $58.5 \pm 23.2$ & $<0.05$ \\
\hline DLco\% (mean \pm SD) & $61.5 \pm 28.5$ & $64.2 \pm 26.0$ & $>0.05$ \\
\hline mMRC dyspnea score (mean \pm SD) & $1.70 \pm 1.11$ & $1.74 \pm 1.10$ & $>0.05$ \\
\hline \multicolumn{4}{|l|}{ Complication, n (\%) } \\
\hline Hypertension & $292(56.3)$ & $135(56.0)$ & $>0.05$ \\
\hline $\mathrm{CHD}$ & $159(30.6)$ & $73(30.3)$ & $>0.05$ \\
\hline Diabetes & $87(16.8)$ & $44(18.3)$ & $>0.05$ \\
\hline Cerebrovascular disease & $55(10.6)$ & $19(7.9)$ & $>0.05$ \\
\hline Liver disease & $21(4.0)$ & $10(4.1)$ & $>0.05$ \\
\hline Kidney disease & $20(3.9)$ & $7(2.9)$ & $>0.05$ \\
\hline Hematology disease & $4(0.8)$ & $2(0.8)$ & $>0.05$ \\
\hline \multicolumn{4}{|l|}{ Exacerbation history } \\
\hline $\begin{array}{l}\text { Number of exacerbations } \\
(\text { mean } \pm \text { SD) }\end{array}$ & $2.47 \pm 2.68$ & $2.55 \pm 2.93$ & $>0.05$ \\
\hline One or more exacerbation $\mathrm{n}(\%)$ & $821(87.0)$ & $386(84.3)$ & $>0.05$ \\
\hline Severe exacerbation, n (\%) & $44 \mid(5 I .6)$ & $185(44.5)$ & $<0.05$ \\
\hline \multicolumn{4}{|l|}{ Quality of life } \\
\hline SF-36_PCS (mean $\pm S D)$ & $55.5 \pm 21.6$ & $53.4 \pm 21.2$ & $>0.05$ \\
\hline SF-36_MCS (mean $\pm S D)$ & $61.3 \pm 25.0$ & $57.5 \pm 26.8$ & $<0.01$ \\
\hline
\end{tabular}

Abbreviations: $\mathrm{CHD}$, coronary heart disease; DLco, carbon monoxide diffusing capacity; RV, residual volume; SF-36_MCS, the short form-36 mental component summary; SF-36_PCS, the short form-36 physical component summary; TLC, total lung capacity; VC, vital capacity.

of COPD. Relative to male patients, more women reported having never heard of COPD before $(67.0 \%$ vs $59.0 \%$, $P<0.01)$. More than half of the women did not know the risk factors of COPD $(53.5 \%$ vs $37.5 \%, P<0.01)$. Less women regarded active smoking, passive smoking, air pollution, biomass, respiratory infection, and occupational exposure as the risk factors of COPD (Table 3).

\section{Patients' attitude about COPD diagnosis}

As for patients' attitude about COPD diagnosis, similar percentage of female and male patients regarded themselves as having COPD $(80.7 \%$ vs $83.1 \%, P>0.05)$. There was no gender difference about whether they would ask physician about the severity of COPD ( $90.6 \%$ vs $92.6 \%, P>0.05)$, as shown in Table 3.

\section{Patients' and physicians' practice about COPD diagnosis}

Relative to the practice on COPD diagnosis, less women had PFT done before $(65.2 \%$ vs $70.4 \%, P<0.05)$. More women reported not repeating PFT annually $(91.7 \%$ vs $87.6 \%$, $P<0.05)$ and being unknown to the PFT results $(78.6 \%$ vs $73.1 \%, P<0.05)$. Less women reported that physician would tell them they have emphysema $(50.5 \%$ vs $60.4 \%, P<0.01)$ or COPD (31.9\% vs 37.9\%, $P<0.05)$. Similar percentage of female and male patients reported that physician would tell them they have chronic bronchitis $(74.8 \%$ vs $77.6 \%, P>0.05)$ and about the severity of COPD ( $28.2 \%$ vs $30.8 \%, P>0.05)$, as shown in Table 3.

\section{Patients' knowledge about COPD treatment}

The knowledge on COPD treatment was evaluated by patients' cognition of drugs' side effects, treatment methods, and goal of COPD treatment. Approximately $80 \%$ of female and male patients did not know the side effects of anticholinergic drugs $(80.1 \%$ vs $81.6 \%)$, $\beta$-adrenergic agonists (79.4\% vs 82.2\%), inhaled corticosteroids (ICSs; $80.0 \%$ vs $80.7 \%$ ), ICS/long-acting $\beta 2$-agonist ( $80.3 \%$ vs $82.7 \%$ ), and theophylline (78.6\% vs $81.4 \%$ ) (all $P>0.05$ ). Lesser women than men reported COPD should be given combined therapy (38.3\% vs 44.5\%) and long-term treatment (46.1\% vs $51.9 \%)($ all $P<0.05)$. They did not differ in the goal of COPD treatment (Table 4).

\section{Patients' attitude on current COPD treatment}

As to patients' attitude on COPD treatment, $>70 \%$ of the female and male patients were satisfied with COPD drugs $(75.1 \%$ vs $77.6 \%, P>0.05)$. Some patients worried about the side effects of ICSs (26.7\% vs $28.0 \%)$. When asked about the factors associated with the "ideal" COPD drug, male and female patients ranked drug efficacy as No $1(69.6 \%$ vs $70.3 \%$ ) and side effects as No $2(36.0 \%$ vs $35.6 \%)$, as shown in Table 5.

\section{Patients' and physicians' practice on COPD treatment}

With regard to the practice on COPD treatment, $84.8 \%$ female and $87.5 \%$ male patients reported use of any respiratory medication for COPD in recent 3 months. The most commonly used drug by women and men was theophylline ( $54.3 \%$ vs $59.1 \%$ ), followed by salbutamol (36.7\% vs 39.0\%), ipratropium 
Table 3 Patients' knowledge, attitude, and practice on COPD diagnosis

\begin{tabular}{|c|c|c|c|}
\hline & Male, n (\%) & Female, n (\%) & $P$-value \\
\hline Never heard of COPD & $682(59.0)$ & $363(67.0)$ & $<0.01$ \\
\hline \multicolumn{4}{|l|}{ Risk factors of COPD } \\
\hline Unknown & 431 (37.5) & $288(53.5)$ & $<0.01$ \\
\hline Active smoking & $655(57.0)$ & $183(34.0)$ & $<0.01$ \\
\hline Passive smoking & $378(32.9)$ & $150(27.9)$ & $<0.05$ \\
\hline Air pollution & $349(30.3)$ & $119(22.1)$ & $<0.01$ \\
\hline Biomass & $176(15.3)$ & $64(11.9)$ & $>0.05$ \\
\hline Respiratory infection & $325(28.3)$ & $122(22.7)$ & $<0.05$ \\
\hline Occupational exposure & $178(\mid 5.5)$ & $52(9.7)$ & $<0.01$ \\
\hline Regard themselves have COPD & $957(83.1)$ & $434(80.7)$ & $>0.05$ \\
\hline Ask physician about the severity of COPD & $1,066(92.6)$ & $489(90.6)$ & $>0.05$ \\
\hline Physician had to tell the patient that he/she has emphysema & $694(60.4)$ & $272(50.5)$ & $<0.01$ \\
\hline Physician had to tell the patient that he/she has chronic bronchitis & $892(77.6)$ & $404(74.8)$ & $>0.05$ \\
\hline Physician had to tell the patient that he/she has COPD & $436(37.9)$ & $172(3 \mid .9)$ & $<0.05$ \\
\hline Physician had to say about the severity of COPD & $354(30.8)$ & $153(28.2)$ & $>0.05$ \\
\hline Have done PFT before & $812(70.4)$ & $353(65.2)$ & $<0.05$ \\
\hline Not repeating PFT yearly & $\mathrm{I}, 0 \mathrm{II}(87.6)$ & $497(91.7)$ & $<0.05$ \\
\hline Not knowing PFT results & $843(73.1)$ & $426(78.6)$ & $<0.05$ \\
\hline
\end{tabular}

Abbreviation: PFT, pulmonary function test.

bromide ( $29.4 \%$ vs $34.2 \%)$, and salmeterol/fluticasone $(28.0 \%$ vs $24.9 \%$ ) (all $P>0.05$ ). Female and male groups reported taking drugs according to the prescription $(62.6 \%$ vs $66.9 \%)$, when they remember $(8.7 \%$ vs $9.4 \%)$, or when needed $(28.7 \%$ vs $23.8 \%$ ). Most of them never adjusted ( $42.3 \%$ vs $44.4 \%$, $P>0.05)$, whereas a small percentage of the patients always adjusted the drug frequency or doses by themselves $(17.2 \% \mathrm{vs}$ $13.4 \%, P<0.05)$. Similar percentage of patients reported using antibiotics very often ( $43.9 \%$ vs $41.2 \%, P>0.05)$. They did not have oxygen supply at home ( $73.9 \%$ vs $68.8 \%, P>0.05)$. More women reported not having had pulmonary rehabilitation before ( $87.8 \%$ vs $83.6 \%, P<0.05)$. They did not ever attend patient education activity held by the hospital (93.7\% vs $91.7 \%, P>0.05)$. Similar percentage of patients reported that physician would introduce the effect of prescribed drugs to them ( $46.4 \%$ vs $47.4 \%, P>0.05$ ), as shown in Table 5 .

Table 4 Patients' knowledge on the goal of COPD treatment

\begin{tabular}{|c|c|c|c|}
\hline & Male, n (\%) & Female, n (\%) & $P$-value \\
\hline \multicolumn{4}{|c|}{ Patients who did not know the side effects of COPD drug } \\
\hline Anticholinergic drugs & $775(8 \mathrm{I} .6)$ & $359(80.1)$ & $>0.05$ \\
\hline Beta-receptor agonist & $778(82.2)$ & $355(79.4)$ & $>0.05$ \\
\hline ICS & $766(80.7)$ & $357(80.0)$ & $>0.05$ \\
\hline ICS/LABA & $784(82.7)$ & $358(80.3)$ & $>0.05$ \\
\hline Theophylline & $773(8 \mid .4)$ & $352(78.6)$ & $>0.05$ \\
\hline \multicolumn{4}{|l|}{ Single or combined therapy } \\
\hline Single therapy & $44(3.9)$ & $30(5.6)$ & $>0.05$ \\
\hline Combined therapy & $508(44.5)$ & $205(38.3)$ & $<0.05$ \\
\hline Do not know/does not matter & $590(51.7)$ & $300(56.1)$ & $>0.05$ \\
\hline \multicolumn{4}{|l|}{ Long-term treatment } \\
\hline Yes & $593(51.9)$ & $247(46.1)$ & $<0.05$ \\
\hline \multicolumn{4}{|l|}{ Goal of COPD treatment } \\
\hline Can be cured & $258(22.4)$ & $124(23.1)$ & $>0.05$ \\
\hline Reduced symptoms & $601(52.1)$ & $296(55.1)$ & $>0.05$ \\
\hline Improved quality of life & $153(13.3)$ & $62(11.5)$ & $>0.05$ \\
\hline No effective treatment & $69(6.0)$ & $28(5.2)$ & $>0.05$ \\
\hline
\end{tabular}

Abbreviations: ICS, inhaled corticosteroid; LABA, long-acting $\beta 2$-agonist. 
Table 5 Patients' practice on current COPD treatment

\begin{tabular}{|c|c|c|c|}
\hline & Male, n (\%) & Female, n (\%) & $P$-value \\
\hline \multicolumn{4}{|l|}{ COPD treatments } \\
\hline Any medication & $594(87.5)$ & $245(84.8)$ & $>0.05$ \\
\hline Theophylline & $402(59.1)$ & $157(54.3)$ & $>0.05$ \\
\hline Salbutamol & $265(39.0)$ & $106(36.7)$ & $>0.05$ \\
\hline Ipratropium bromide & $232(34.2)$ & $85(29.4)$ & $>0.05$ \\
\hline Salmeterol/fluticasone & $169(24.9)$ & $81(28.0)$ & $>0.05$ \\
\hline Tiotropium & III (I6.3) & $40(13.8)$ & $>0.05$ \\
\hline Budesonide & $77(11.3)$ & $29(10.0)$ & $>0.05$ \\
\hline Oral beta agonist & $42(6.2)$ & $20(6.9)$ & $>0.05$ \\
\hline Formoterol/budesonide & $36(5.3)$ & II (3.8) & $>0.05$ \\
\hline Formoterol & $20(2.9)$ & $8(2.8)$ & $>0.05$ \\
\hline Beclomethasone & $19(2.8)$ & $5(1.7)$ & $>0.05$ \\
\hline Fluticasone & $8(1.2)$ & $5(1.7)$ & $>0.05$ \\
\hline \multicolumn{4}{|l|}{ When the drugs are taken } \\
\hline According to prescription & 749 (66.9) & $325(62.6)$ & $>0.05$ \\
\hline When I remember & $105(9.4)$ & $45(8.7)$ & $>0.05$ \\
\hline When needed & $266(23.8)$ & $149(28.7)$ & $<0.05$ \\
\hline \multicolumn{4}{|l|}{ Patient adjusts the drug frequency or doses } \\
\hline Never & $496(44.4)$ & $219(42.3)$ & $>0.05$ \\
\hline Seldom & $325(29.1)$ & $136(26.3)$ & $>0.05$ \\
\hline A few times & $120(10.8)$ & $56(10.8)$ & $>0.05$ \\
\hline Often & $25(2.2)$ & $18(3.5)$ & $>0.05$ \\
\hline Always & $150(13.4)$ & $89(17.2)$ & $<0.05$ \\
\hline \multicolumn{4}{|l|}{ Patients' satisfaction with COPD drugs } \\
\hline Extremely dissatisfied & II (I.0) & $10(2.0)$ & $>0.05$ \\
\hline Dissatisfied & $223(20.3)$ & $116(22.9)$ & $>0.05$ \\
\hline Satisfied somewhat & $395(35)$ & $172(34)$ & $>0.05$ \\
\hline Satisfied & $380(34.7)$ & $166(32.8)$ & $>0.05$ \\
\hline Extremely satisfied & $87(7.9)$ & $42(8.3)$ & $>0.05$ \\
\hline Worried about the side effects of ICSs & $319(28.0)$ & $142(26.7)$ & $>0.05$ \\
\hline Use antibiotics very often & $473(4 I .2)$ & $237(43.9)$ & $>0.05$ \\
\hline Oxygen supply at home & $792(68.8)$ & $400(73.9)$ & $>0.05$ \\
\hline Pulmonary rehabilitation & $962(83.6)$ & $473(87.8)$ & $<0.05$ \\
\hline \multicolumn{4}{|l|}{ Factors associated with the "ideal" COPD drug } \\
\hline Drug efficacy & $805(69.6)$ & $381(70.3)$ & $>0.05$ \\
\hline Side effects & $416(36.0)$ & $193(35.6)$ & $>0.05$ \\
\hline \multicolumn{4}{|l|}{ Attending patient education activity held by the hospital } \\
\hline Yes & $34(8.3)$ & $95(6.3)$ & $>0.05$ \\
\hline No & I,049 (9I.7) & $503(93.7)$ & $>0.05$ \\
\hline Physician introduced the effect of prescribed drugs & $531(47.4)$ & $242(46.4)$ & $>0.05$ \\
\hline
\end{tabular}

Abbreviation: ICSs, inhaled corticosteroids.

\section{Factors associated with patients' knowledge, attitude, and practice on COPD}

Using "never heard of COPD before" as the outcome variable about patients' knowledge on COPD, we did logistic regression analysis and found that after adjustment of age, education, income, insurance, smoking pack-years, mMRC, $\mathrm{FEV}_{1} \%$, lower income $(<1,000 \mathrm{RMB}, \mathrm{OR} 1.790,95 \% \mathrm{CI}$ 1.279-2.505), $\mathrm{FEV}_{1} \%$ (OR 1.025, 95\% CI 1.017-1.033), and having insurance (OR $0.552,95 \%$ CI $0.375-0.811$ ) among male patients and having insurance (OR 0.273, 95\% CI 0.123-0.604) among female patients remained the independent variables associated with patients' knowledge on COPD (Table 6).

\section{Discussion}

The surveys represented the first coordinated national surveys of gender difference on knowledge, attitude, and practice of COPD in China. It revealed that female and male patients had different experiences on COPD and its treatment. The 
Table 6 Multivariable adjusted ORs for patients' knowledge on COPD

\begin{tabular}{|c|c|c|c|c|}
\hline & \multicolumn{2}{|l|}{ Male } & \multicolumn{2}{|l|}{ Female } \\
\hline & OR $(95 \% \mathrm{Cl})$ & $P$-value & OR $(95 \% \mathrm{Cl})$ & $P$-value \\
\hline Age & $\mathrm{I} .008(0.994-1.022)$ & 0.263 & $0.994(0.954-1.036)$ & 0.766 \\
\hline Smoking pack-years & $1.003(0.998-1.008)$ & 0.284 & $1.001(0.987-1.016)$ & 0.838 \\
\hline $\mathrm{FEV}_{1} \%$ & $1.025(1.017-1.033)$ & 0.000 & $1.016(0.996-1.035)$ & 0.112 \\
\hline \multicolumn{5}{|l|}{ Education level } \\
\hline Low education (under elementary level) & $0.932(0.688-1.262)$ & 0.648 & $2.230(0.992-5.013)$ & 0.052 \\
\hline High education & I.0 (ref) & - & $\mathrm{I} .0$ (ref) & - \\
\hline \multicolumn{5}{|l|}{ Insurance } \\
\hline Have insurance & $0.552(0.375-0.81 \mathrm{I})$ & 0.002 & $0.273(0.123-0.604)$ & 0.001 \\
\hline Self-paid & $\mathrm{I} .0$ (ref) & - & $\mathrm{I} .0$ (ref) & - \\
\hline \multicolumn{5}{|l|}{ Income level } \\
\hline Monthly income $\leq \mathrm{I}, 000 \mathrm{RMB}$ & $1.790(1.279-2.505)$ & 0.001 & $0.596(0.266-1.333)$ & 0.207 \\
\hline Monthly income $>$ I,000 RMB & $\mathrm{I} .0$ (ref) & - & $\mathrm{I} .0$ (ref) & - \\
\hline \multicolumn{5}{|l|}{ Dyspnea severity } \\
\hline $\mathrm{mMRC}<2$ & $\mathrm{I} .0$ (ref) & - & $\mathrm{I} .0$ (ref) & - \\
\hline $\mathrm{mMRC} \geq 2$ & $1.006(0.753-1.343)$ & 0.970 & $1.562(0.774-3.150)$ & 0.213 \\
\hline
\end{tabular}

Abbreviation: ref, reference.

knowledge on COPD was poor in COPD patients, more measures should be taken to improve patients' knowledge on COPD, especially women. It is evident that gender differences in disease impact, expression, progression, and response to therapy were noted in COPD. ${ }^{22}$ However, studies on gender difference in experience and management are lacking. Focused investigation in this area is clearly warranted.

Studies suggested that COPD had different impacts on patient physiology and psychology between males and females. In the present study, relative to male patients, female patients were younger, had higher body mass index, were more never smokers, and had lesser pack-years. More female patients were farmers, with under elementary education level, a monthly income of $<1,000 \mathrm{RMB}$, and without medical insurance or work. Although female patients had higher $\mathrm{FEV}_{1} / \mathrm{FVC}, \mathrm{FEV}_{1} \%$, vital capacity \%, and lower residual volume/total lung capacity, they had similar mMRC dyspnea score, the number of exacerbations in the past year, and lower SF-36 mental component summary. The gender differences on COPD were also revealed in other surveys. Our large national survey conducted in 2014-2015 estimated that the prevalence of COPD in Chinese people aged 40 years and older was $13.6 \% .{ }^{23}$ In the study, there were great differences between men and women in the prevalence, the smoking status, and the severity of COPD. The prevalence of COPD in men was $19.0 \%$, whereas it was $8.1 \%$ among women; as to the smoking status, almost all current smokers were men $(58.2 \%)$, whereas only $4.0 \%$ were women, and men had a higher prevalence in COPD of GOLD stage II-IV than women. ${ }^{23}$ Another national prevalence study undertaken in 2012-2015 showed similar results, that men had a higher prevalence $(11.9 \%)$ than women $(5.4 \%) .^{2}$ Women had a poorer understanding of their condition than men; less female patients had a PFT done before than male patients. ${ }^{2}$ These two national surveys identified the prevalence of COPD in China and its risk factors, but did not focus on the gender difference of COPD, and our study made a further investigation on the gender difference of COPD. The confronting COPD international survey was performed in the USA, Canada, France, Italy, Germany, the Netherlands, Spain, and the UK in 2000 with 3,265 COPD participants. Forty-one percent of them were women. Women were younger and had lesser pack-years of smoking. They were more likely to report severe dyspnea than men, with similar cough and less sputum. There were no differences in the risk of hospitalization or emergency room visit. ${ }^{24}$ Also, there were significant differences in the clinical expression of COPD between men and women, with women scoring lower on health status questionnaires, manifesting worse dyspnea scores, and experiencing more exacerbations than men..$^{25} \mathrm{~A}$ study from Spain showed that women COPD patients were significantly younger, had better PTF, smoked less, but had worse quality of life and higher anxiety and depression. ${ }^{26}$ Another probe revealed that at the same age and $\mathrm{FEV}_{1} \%$ predicted, women were more likely to have dyspnea and worse quality of life (the St George's respiratory questionnaire and SF-36 health survey questionnaire) and worse scores on the Morale Scale that measures subjective well-being, but less sputum. ${ }^{27}$ Evidence indicates that men and women may be phenotypically different in their response to tobacco smoke, with men being more prone to an emphysematous phenotype and women to an airway predominant phenotype..$^{18}$ Also, women were more 
likely to be undiagnosed by general practitioners. ${ }^{15}$ These studies indicated that gender differences in COPD physiology and psychology existed in different studies. Female COPD patients should be given more attention.

In the study, we used knowledge, attitude, and practice (KAP) questionnaire to evaluate patients' knowledge, attitude, and practice on COPD, instead of validated questionnaires such as the Bristol COPD Knowledge Questionnaire (BCKQ) for some reasons. The BCKQ contains 13 topics and it is widely used to assess patients' knowledge about COPD. It also works well in assessing the effectiveness of education and enables comparison of different teaching methods. ${ }^{28}$ Because it focuses on the education of COPD knowledge, it has limitation in assessing COPD patients' attitude and practice and it is not close enough to the clinic to some extent. The KAP questionnaire we used in the article is more comprehensive and closer to clinic than BCKQ, so we chose the KAP questionnaire instead of validated questionnaires such as BCKQ.

Our results showed that COPD patients had a poor understanding of COPD assessed by the items they heard of COPD, the risk factors of COPD, knowledge of the side effects, and COPD treatment. Other studies also showed the same results. A study conducted in Guizhou and Chongqing, China, revealed patients' knowledge on COPD measured by BCKQ and found that patients' knowledge about COPD was poor, the mean BCKQ score was $30.36 \pm 5.59$, and patients' knowledge level was a risk factor of anxiety and depression. ${ }^{29}$ Another study recruited 100 patients in Hong Kong, China, to assess patients' knowledge of COPD, the mean score of BCKQ was $41.01 \pm 10.64$, and there was no gender difference on the knowledge of COPD. ${ }^{30}$ The two Chinese surveys had some limitations in evaluating patients' knowledge on COPD, the number of participants was limited, and most participants were from a single center which could not represent national population. Another survey undertaken in the West Midlands, UK, investigated self-management behavior and support among COPD patients and explored the behavior associated with having a self-management plan. The results indicated that the knowledge on COPD was also poor with a mean BCKQ of $31.5 \pm 10.7 .{ }^{31} \mathrm{~A}$ study showed that COPD education delivered in primary care increased patients' knowledge on COPD; the participants' BCKQ scores in the experimental group and the control group were 27.6 \pm 8.7 and $29.6 \pm 7.9$, respectively, at baseline. ${ }^{32}$ In general, the knowledge on COPD was limited worldwide, and our survey found that patients, especially women, had a poor knowledge of COPD in China. We should pay more attention to women's education on COPD.
The current survey revealed the differences in male and female patients' attitudes about COPD. Relative to male patients, more female patients reported having never heard of COPD before, not repeating PFT annually, and being unknown to the PFT results. Less female patients had done PFT before and reported that the physician would tell them they have emphysema or COPD. The results were consistent with our previous study in Yanqing District, China. ${ }^{33}$ We evaluated the patients' comprehension, recognition, and burden of COPD in the rural area of Beijing. Of the 1,624 people aged $>40$ in five villages in Yanqing District of Beijing, 148 were diagnosed to have COPD. None of them had ever heard the term COPD and been diagnosed with COPD. Lung function tests and health education had never been performed for these patients. ${ }^{33}$ In our national epidemiology survey, about $9.7 \%$ of adults had a PTF done before; ${ }^{2}$ but in our survey, we found a higher rate of PFT done before than other national and international surveys, ${ }^{2,23,34}$ which may be attributed to the reason that patients recruited were from clinics in tertiary hospitals and some of them may have visited physicians in primary care or secondary hospitals before. Despite this, over $70 \%$ of patients did not know their PFT results. Patients' knowledge of COPD was limited. Patients considered themselves to be uninformed about COPD and obtained most of their information from physicians. A nationwide survey in the USA showed that about $45.6 \%$ of the COPD patients were aware of COPD guidelines, but men were better informed. ${ }^{35}$ Also, they had sufficient sources of COPD education, as along with physician, respiratory therapist, and nurse, they also got information about COPD on books, magazines, other patients, television or cable, patient organizations, online support groups, and other Internet resources..$^{35}$ The results showed that patients had a poor understanding of COPD in China and patients had a few sources, except from the physician, for learning about COPD. Health education should play an important role in the management of COPD in China, particularly among females.

Whether women received the same medical care for COPD as men is not known. We found that the most commonly used drugs by female and male patients in the recent 3 months were theophylline, followed by albuterol, ipratropium bromide, and salmeterol/fluticasone. The results were equal to another survey conducted in Sweden, which showed that drug treatment depended on disease severity. ${ }^{36}$ More than $70 \%$ of the patients were satisfied with COPD drugs. Approximately $80 \%$ of the patients did not know the side effects of anticholinergic drugs, $\beta$-adrenergic agonists, ICSs, ICS/long-acting $\beta 2$-agonist, and theophylline. Similar 
percentage of female and male patients reported using antibiotics very often. They did not have oxygen supply at home. Relative to male patients, more female patients reported not having had pulmonary rehabilitation before and lesser number of females reported COPD should be given combined therapy and long-term treatment. In our previous study in Yanqing District, only $4.1 \%$ of the patients in stable stage took theophylline irregularly. ${ }^{33}$ None of the stable COPD patients took inhalers regularly or temporally. No oxygen therapy and pulmonary rehabilitation were done in those patients. During acute exacerbations, only $6.8 \%$ took theophylline and $6.8 \%$ had antibiotics, and the management of both stable and exacerbation of COPD was inadequate..$^{33}$ The results indicated that patients, especially women, were unfamiliar with COPD guidelines.

In our study, more women were farmers, with under elementary education level, a monthly income $<1,000$ RMB, and without medical insurance or work. Using "never heard of COPD before" as the outcome variable about patients' knowledge on COPD, we did logistic regression analysis and found that lower income and $\mathrm{FEV}_{1} \%$ in male patients had a negative effect on the knowledge of COPD, and self-paid insurance in female and male patients enhanced patients' knowledge on COPD. Optimal care is impeded by suboptimal knowledge of physicians and patients and by not having insurance coverage policies.

The current study had several limitations. The study design was not a population survey, and patients were selected from clinics in hospitals consecutively and not by random selection; therefore, it might have a selection bias. About $50 \%-60 \%$ of the patients were GOLD stage III and IV; they may have different perceptions of COPD and treatment, compared with stage I and II patients. Secondly, there is heterogeneity in drug availability in different centers. We did not compare the differences among centers.

\section{Conclusion}

In summary, our data indicate that male and female patients had different experiences on COPD and its treatment. Physician should pay more attention to patient education, especially of females, using various ways such as television, Internet, and lecture to improve their knowledge and management of COPD.

\section{Acknowledgments}

We acknowledge the substantial contributions to the conception and design and acquisition of data by Jian Kang, MD of The First Hospital Affiliated to the China Medical University; Baiqiang Cai, MD of Peking Union Hospital,
Beijing; Xin Zhou, MD of the First People's Hospital in Shanghai; Zheng Liu, MD of China Oil and Gas Group Central Hospital; Ping Chen, MD of Shenyang Military General Hospital; Dejun Sun, MD of Inner Mongolia Autonomous Region People's Hospital; Jinping Zheng, MD of the Institute of Respiratory Disease; Guoyang Wang of Jingmei Group General Hospital; Yulin Feng of West China Hospital; and Yongjian Xu of Tongji Hospital, affiliated to Huazhong Science and Technology University. The study is supported by the Research Special Fund for Public Welfare Industry of Health (201002008), Chinese Medical Association Chronic Respiratory Disease Fund (No 07010360044), 12th Five-Year National Science and Technology Support Program (2013BAI06B02), and National Key Research and Development Project (No 2016YFC1304301). The abstract of this paper was presented at the 17th Conference of the Asian Pacific Society of Respirology as a poster presentation with interim findings. The poster's abstract was published in "Poster Abstracts" in Respirology.

\section{Author contributions}

Guohua Jia, Ming Lu, Rui Wu, Yahong Chen, and Wanzhen Yao were responsible for the conception and design, acquisition of data, analysis and interpretation of data, drafting the article or revising it critically for important intellectual content, and final approval of the version to be published, and all agree to be accountable for all aspects of the work in ensuring that questions related to the accuracy or integrity of any part of the work are appropriately investigated and resolved. All authors have read the manuscript and approve its submission.

\section{Disclosure}

The authors report no conflicts of interest in this work.

\section{References}

1. Zhou M, Wang H, Zhu J, et al. Cause-specific mortality for 240 causes in China during 1990-2013: a systematic subnational analysis for the Global Burden of Disease Study 2013. Lancet. 2016;387(10015):251-272.

2. Wang C, Xu J, Yang L, et al. Prevalence and risk factors of chronic obstructive pulmonary disease in China (the China Pulmonary Health [CPH] study): a national cross-sectional study. Lancet. 2018;391(10131): 1706-1717.

3. Zhong N, Wang C, Yao W, et al. Prevalence of chronic obstructive pulmonary disease in China: a large, population-based survey. Am J Respir Crit Care Med. 2007;176(8):753-760.

4. Aryal S, Diaz-Guzman E, Mannino DM. COPD and gender differences: an update. Transl Res. 2013;162(4):208-218.

5. Akinbami LJ, Liu X. Chronic obstructive pulmonary disease among adults aged 18 and over in the United States, 1998-2009. NCHS Data Brief. 2011;63(63):1-8.

6. Bischoff EW, Schermer TR, Bor H, Brown P, van Weel C, van den Bosch WJ. Trends in COPD prevalence and exacerbation rates in Dutch primary care. Br J Gen Pract. 2009;59(569):927-933. 
7. Doucet M, Rochette L, Hamel D, Incidence HD. Incidence, prevalence, and mortality trends in chronic obstructive pulmonary disease over 2001 to 2011: a public health point of view of the burden. Can Respir J. 2016;2016:1-10.

8. Camp PG, Ramirez-Venegas A, Sansores RH, et al. COPD phenotypes in biomass smoke- versus tobacco smoke-exposed Mexican women. Eur Respir J. 2014;43(3):725-734.

9. Amaral AFS, Strachan DP, Burney PGJ, Jarvis DL. Female smokers are at greater risk of airflow obstruction than male smokers. UK Biobank. Am J Respir Crit Care Med. 2017;195(9):1226-1235.

10. Miller MR, Jordan RE, Adab P. Gender differences in COPD: are women more susceptible to smoking effects than men? Thorax. 2011;66(10):921-922.

11. Gordon SB, Bruce NG, Grigg J, et al. Respiratory risks from household air pollution in low and middle income countries. Lancet Respir Med. 2014;2(10):823-860.

12. Lou $\mathrm{P}, \mathrm{Zhu} \mathrm{Y}$, Chen $\mathrm{P}$, et al. Vulnerability of patients with chronic obstructive pulmonary disease according to gender in China. Int $J$ Chron Obstruct Pulmon Dis. 2012;7:825-832.

13. Zhao D, Zhou Y, Jiang C, Zhao Z, He F, Ran P. Small airway disease: a different phenotype of early stage COPD associated with biomass smoke exposure. Respirology. 2018;23(2):198-205.

14. Lamprecht B, Mcburnie MA, Vollmer WM, et al. COPD in never smokers: results from the population-based burden of obstructive lung disease study. Chest. 2011;139(4):752-763.

15. Delgado A, Saletti-Cuesta L, Lopez-Fernandez LA, Gil-Garrido N, Luna del Castillo JD. Gender inequalities in COPD decision-making in primary care. Respir Med. 2016;114:91-96.

16. Zhou Y, Zhong NS, Li X, et al. Tiotropium in early-stage chronic obstructive pulmonary disease. $N$ Engl J Med. 2017;377(10):923-935.

17. Wilkinson TM, Donaldson GC, Hurst JR, Seemungal TA, Wedzicha JA. Early therapy improves outcomes of exacerbations of chronic obstructive pulmonary disease. Am J Respir Crit Care Med. 2004;169(12): 1298-1303.

18. Hong Y, Ji W, An S, Han SS, Lee SJ, Kim WJ. Sex differences of COPD phenotypes in nonsmoking patients. Int J Chron Obstruct Pulmon Dis. 2016;11:1657-1662.

19. Chronic Obstructive Pulmonary Disease Committee, Respiratory Society, Chinese Medical Association. Guidelines for the diagnosis and treatment of chronic obstructive pulmonary disease (2013 edition). Zhonghua Jie He He Hu Xi Za Zhi. 2013;36(4):67-80.

20. Li L, Wang H, Shen Y. Development and psychometric tests of a Chinese version of the SF-36 Health Survey Scales. Zhonghua Yu Fang Yi Xue Za Zhi. 2002;36(2):109-113.

21. Vogelmeier CF, Criner GJ, Martinez FJ, et al. Global strategy for the diagnosis, management, and prevention of chronic obstructive lung disease 2017 report. GOLD executive summary. Am J Respir Crit Care Med. 2017;195(5):557-582.

22. Kokturk N, Kilic H, Baha A, Lee SD, Jones PW. Sex difference in chronic obstructive lung disease. Does it matter? A concise review. COPD. 2016;13(6):799-806.
23. Fang L, Gao P, Bao H, et al. Chronic obstructive pulmonary disease in China: a nationwide prevalence study. Lancet Respir Med. 2018; 6(6):421-430.

24. Watson L, Vestbo J, Postma DS, et al. Gender differences in the management and experience of chronic obstructive pulmonary disease. Respir Med. 2004;98(12):1207-1213.

25. Celli B, Vestbo J, Jenkins CR, et al. Sex differences in mortality and clinical expressions of patients with chronic obstructive pulmonary disease. The TORCH experience. Am J Respir Crit Care Med. 2011;183(3):317-322.

26. Naberan K, Azpeitia A, Cantoni J, Miravitlles M. Impairment of quality of life in women with chronic obstructive pulmonary disease. Respir Med. 2012;106(3):367-373.

27. Katsura H, Yamada K, Wakabayashi R, Kida K. Gender-associated differences in dyspnoea and health-related quality of life in patients with chronic obstructive pulmonary disease. Respirology. 2007; 12(3):427-432.

28. White R, Walker P, Roberts S, Kalisky S, White P. Bristol COPD Knowledge Questionnaire (BCKQ): testing what we teach patients about COPD. Chron Respir Dis. 2006;3(3):123-131.

29. Zhang Q, Liao J, Liao X, et al. Disease knowledge level is a noteworthy risk factor of anxiety and depression in patients with chronic obstructive pulmonary disease: a cross-sectional study. BMC Pulm Med. 2014;14(1): 92-97.

30. Wong CK, Yu WC. Correlates of disease-specific knowledge in Chinese patients with COPD. Int J Chron Obstruct Pulmon Dis. 2016; 11(1):2221-2227.

31. Khan A, Dickens AP, Adab P, Jordan RE. Self-management behaviour and support among primary care COPD patients: cross-sectional analysis of data from the Birmingham Chronic Obstructive Pulmonary Disease Cohort. NPJ Prim Care Respir Med. 2017;27(1):46-56.

32. Hill K, Mangovski-Alzamora S, Blouin M, et al. Disease-specific education in the primary care setting increases the knowledge of people with chronic obstructive pulmonary disease: a randomized controlled trial. Patient Educ Couns. 2010;81(1):14-18.

33. Shen N, Yao W, Zhu H. Patient's perspective of chronic obstructive pulmonary disease in Yanqing County of Beijing. Zhonghua Jie He He Hu Xi Za Zh. 2008;31(3):206-208.

34. Lamprecht B, Soriano JB, Studnicka M, Bernd L, Joan BS, Michael S. Determinants of underdiagnosis of COPD in national and international surveys. Chest. 2015;148(4):971-985.

35. Martinez CH, Raparla S, Plauschinat CA, et al. Gender differences in symptoms and care delivery for chronic obstructive pulmonary disease. $J$ Womens Health (Larchmt). 2012;21(12):1267-1274.

36. Henoch I, Strang S, Löfdahl CG, Ekberg-Jansson A. Management of COPD, equal treatment across age, gender, and social situation? A register study. Int J Chron Obstruct Pulmon Dis. 2016;11:2681-2690. 


\section{Supplementary material}

The KAP Questionnaire on COPD

I. Patients' knowledge of COPD diagnosis and treatment

1. Have you ever heard of COPD before?

2. Which disease is associated with COPD?

Chronic bronchitis or emphysema

3. Which item is a risk factor of COPD?

Active smoking

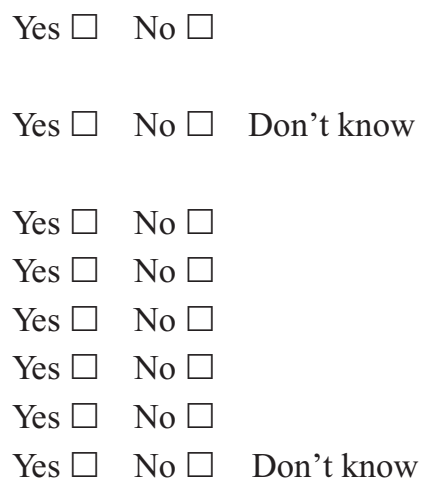

Passive smoking

Air pollution

Biomass

Respiratory infection

Occupational exposure

Yes $\square \quad$ No $\square$

Don't know

\section{What's the clinical feature of COPD?}

Cough

Expectoration

Yes $\square \quad$ No $\square$

Dyspnea

Yes $\square \quad$ No $\square$

Yes $\square \quad$ No $\square$

Don't know

\section{What's the clinical feature of COPD exacerbation?}

Upper respiratory infection

Increased dyspnea

Increased sputum volume

Sputum purulence

Increased cough

Fever

6. What's the warning sign of coming COPD exacerbation?

Wheeze

Yes $\square \quad$ No $\square$

Yes $\square \quad$ No $\square$

Yes $\square \quad$ No $\square$

Yes $\square \quad$ No $\square$

Yes $\square$ No $\square$

Lacking of strength

Upper respiratory infection

Yes $\square$ No $\square$ Don't know

Increased cough

Increased sputum

No warning signs or don't know

Yes $\square \quad$ No $\square$

Yes $\square \quad$ No $\square$

Yes $\square \quad$ No

Yes $\square \quad$ No $\square$

Yes $\square \quad$ No $\square$

Yes $\square \quad$ No $\square$

7. What's the side effect of most used COPD drugs? Please list the side effect if you choose yes.

Anticholinergic drug

Beta receptor agonist

Inhaled corticosteroids

ICS/LABA

Theophylline

8. Do you think COPD should use combined treatment or single treatment?

Single treatment

Combined treatment

Don't know

9. Does COPD need long-term therapy?

Yes $\square$

$$
\text { No } \square
$$

Don’t know

Yes $\square \quad$ No $\square$
Yes $\square \quad$ No $\square$
Yes $\square$ No $\square$
Yes $\square \quad$ No $\square$
Yes $\square \quad$ No $\square$

Yes $\square \quad$ No $\square$

Yes $\square \quad$ No $\square$

Yes $\square \quad$ No $\square$

Yes $\square$ No $\square$ 
10. What's the right description on goal of COPD treatment?

Can be cured

Alleviate symptoms

Improve quality of life

$\begin{array}{cl}\text { Yes } \square & \text { No } \square \\ \text { Yes } \square & \text { No } \square \\ \text { Yes } \square & \text { No } \square \\ \text { Yes } \square & \text { No } \square\end{array}$

No effective treatment

II. Patients' attitude of COPD diagnosis and treatment

1. Do you regard yourself have chronic bronchitis, emphysema or COPD? $\quad$ Yes $\square \quad$ No $\square$

2. Would you ask physician about the severity of COPD?

Yes $\square \quad$ No $\square$

3. Which did you worry most in a COPD exacerbation?

Death $\square$ The exacerbation of syndrome $\square$ Hospitalization $\square$ Decline of lung function $\square$

4. Which item best describes your satisfaction with COPD drugs?

Extremely dissatisfied $\square \quad$ Dissatisfied $\square \quad$ Satisfied somewhat $\square \quad$ Satisfied $\square \quad$ Extremely satisfied $\square$

5. These are factors associated with the "ideal" COPD drug, please rank them by importance?
A. Drug efficacy
B. Type of dose C. Side effects
D. The size and shape
E. Price F. Frequency of dose
6. Do you worry about side effect of ICS?
Yes $\square \quad$ No $\square \quad$ Don't know

III. Patients' practice of COPD diagnosis and treatment

1. What medicines do you take to treat your COPD?

Theophylline $\square$ Salbutamol $\square \quad$ Ipratropium bromide $\square \quad$ Salmeterol/fluticasone $\square \quad$ Tiotropium $\square \quad$ Budesonide $\square$ Oral beta agonist $\square \quad$ Formoterol/budesonide $\square$ Formoterol $\square \quad$ Beclomethasone

2. Had Physician told you that you have emphysema?

3. Had Physician told you that you have chronic bronchitis?

$\begin{array}{cc}\text { Yes } \square & \text { No } \square \\ \text { Yes } \square & \text { No } \square \\ \text { Yes } \square & \text { No } \square \\ \text { Yes } \square & \text { No } \square \\ \text { Yes } \square & \text { No } \square \\ \text { Yes } \square & \text { No } \square \\ \text { Yes } \square & \text { No } \square \\ \text { Yes } \square & \text { No } \square\end{array}$

4. Had Physician told you that you have COPD?

5. Had Physician told you the severity of your COPD?

6. Had you ever done PFT before?

7. Do you repeat PFT yearly?

8. Do you know your PFT results?

9. Had physician introduce the effect of prescribed drugs?

10. When did you take drugs?

According to prescription $\square \quad$ When remember $\square \quad$ When needed

11. How often do you adjust drug frequency or doses without doctors' instructions?

Never $\square \quad$ Seldom $\square \quad$ A few $\square \quad$ Often $\square \quad$ Always

12. Did you use antibiotics very often?

Yes $\square \quad$ No $\square$

13. Do you have oxygen supply at home? If you have one, did you use it often or treat it as a standby?

Use it often $\square \quad$ Standby $\square \quad$ Don't have one

14. Had you attended a pulmonary rehabilitation program?

15. Did you attend patients' education activity held by hospital?

Yes $\square \quad$ No $\square$
Yes $\square \quad$ No $\square$

International Journal of COPD

Dovepress

\section{Publish your work in this journal}

The International Journal of COPD is an international, peer-reviewed journal of therapeutics and pharmacology focusing on concise rapid reporting of clinical studies and reviews in COPD. Special focus is given to the pathophysiological processes underlying the disease, intervention programs, patient focused education, and self management protocols.

This journal is indexed on PubMed Central, MedLine and CAS. The manuscript management system is completely online and includes a very quick and fair peer-review system, which is all easy to use. Visit http://www.dovepress.com/testimonials.php to read real quotes from published authors. 